Contents List available at VOLKSON PRESS

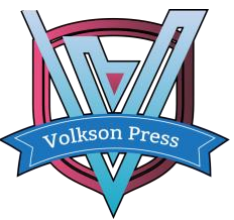

Intelligent Computing and Information Engineering (ICIE )

DOI : http://doi.org/10.26480/icie.01.2017.71.73

Journal Homepage: : https://www.intelcomp-design.com/

\title{
ANALYSIS OF INBOUND TOURISM MARKET STRUCTURE OF GUANGXI PROVINCE
}

Yu Tong

He Yuan Polytechnic, He Yuan, Guangdong, China

*Corresponding author email: 86282557@qq.com

This is an open access article distributed under the Creative Commons Attribution License, which permits unrestricted use, distribution, and reproduction in any medium, provided the original work is properly cited

\section{ARTICLE DETAILS}

\section{Article History:}

Received 12 May2017

Accepted 12 July 2017

Available online 14 September 2017

Keywords:

Guangxi Province, inbound

tourism, Tourist market,

\section{ABSTRACT}

Based on the data related to the inbound tourism in Guangxi Province from 2006 to 2015, the structure of inbound tourist market is anatomized. As the result indicates, the inbound tourism market of Guangxi has increased yearly in concentration index, which bespeaks that the origin region of tourists is concentrated in spatial distribution and low in anti-risk capacity, not conducing to the stable development of the inbound tourism market. Foreigners take up the major place in the inbound tourism market of Guangxi Province, and tourists from Hong Kong, Macao, Taiwan, Vietnam, Korea and Malaysia take up the most important place in the inbound tourism market in Guangxi. For this reason, the measures shall be adopted to boost the stable development of these markets.

structure.

\section{Introduction}

Guangxi Zhuang Autonomous Region is located in the west of Southern China, facing the Southeast Asia, and adjoining Vietnam on the southwest. This province takes up the major place in the economic communication between China and Southeast Asia. Guangxi possesses the scenic landscape of Guilin and the gorgeous and unique folk-custom of minority. In each year, numerous foreign tourists have been attracted to this place for sightseeing. Since the launching of reform and opening up, the inbound tourism in Guangxi has been developing by leaps and bounds, with the continuously increased number of inbound tourists and the foreign exchange receipt from tourism. From Figure 1, it is acquired that the number of inbound tourists in Guangxi Province has increased from 1.676 million people in 2006 to 4.501 million in 2015, indicating an increase of 168.6\%. The foreign exchange receipt from tourism in Guangxi Province has increased from 0.394 billion USD in 2006 to 1.917 USD in 2015, indicating an increase of 386.5\% and bespeaking the rapid development. To understand the developing status of Guangxi's inbound tourism more comprehensively, 13 major inbound tourist countries and regions are selected as the research objects, including Hong Kong, Macao, Taiwan, Vietnam, Korea, Malaysia, Singapore, America, Indonesia, Thailand, France, Britain, Japan, Germany and Australia. In accordance with the relevant data presented by the outline of Guangxi tourism statistics (2007-2016) and through adopting the Excel software, the inbound tourism market structure of Guangxi Province is anatomized as to provide the preference for competent tourism department to develop the inbound tourism.

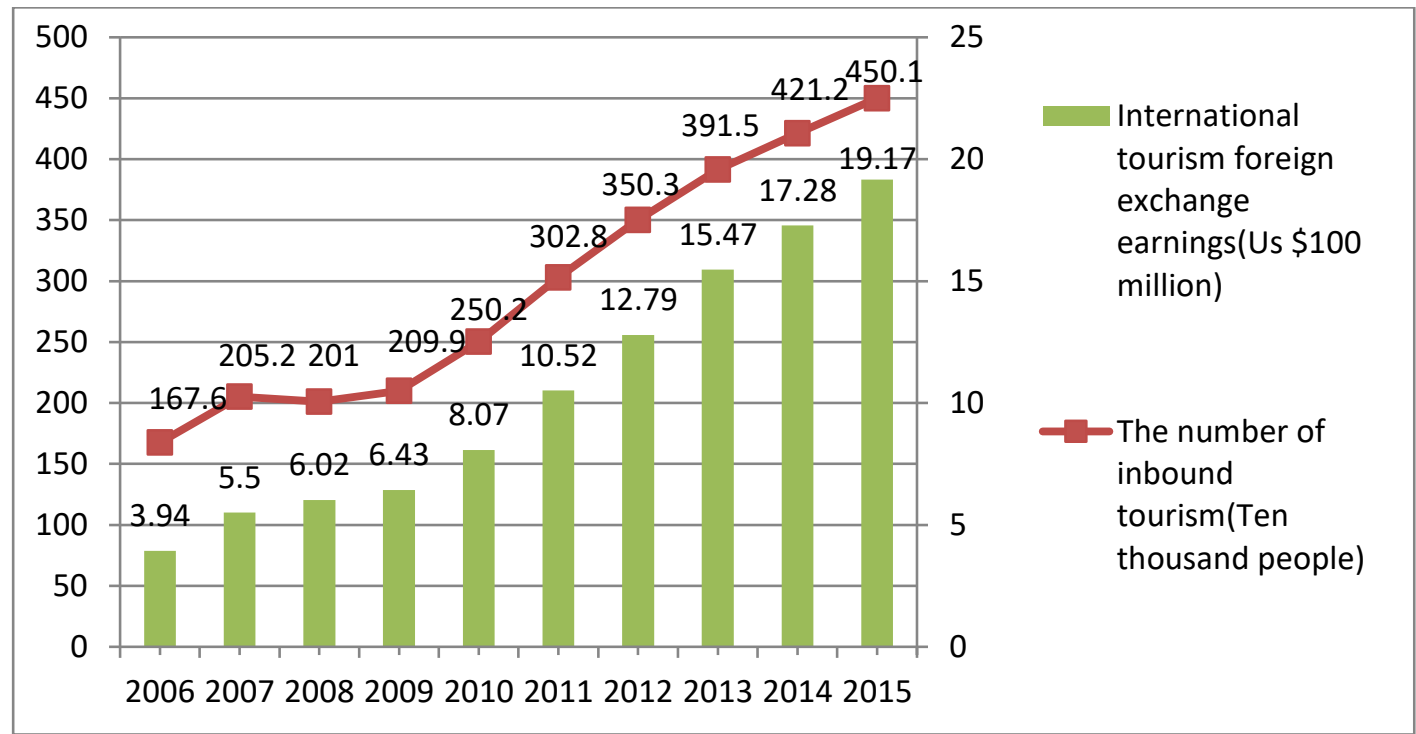

Figure 1: Annual Changes of Inbound Tourist Number and Foreign Exchange Receipt in Tourism of Guangxi Province from 2006 to 2015

\section{ANALYSIS OF INBOUND TOURIST SOURCE STRUCTURE IN GUANGXI PROVINCE}

\subsection{Analysis of Spatial Structure of Tourist's Origin Region}


The geographic concentration indexes adopted by scholars of tourism geography to research the geographical origin and spatial distribution of tourists, indicating the concentration condition of tourist market distribution in the tourism destination [1]. Such index is bespoken through mathematical formula as:

$\mathrm{G}=100 \times \sqrt{\sum_{i=1}^{n}\left(\frac{X_{i}}{T}\right)^{2}}$

Where G refers to the geographical concentration index, $\mathrm{X}^{i}$ refers to the tourist number of the ${ }^{i}$ th origin country, $\mathrm{T}$ refers to the total number of tourists in the destination, $\mathrm{n}$ refers to the total sample number of main origin countries and regions. The less valued $\mathrm{G}$ bespeaks that the origin countries and regions of tourists are more dispersive, and the inbound tourist market tends to be stable, conducing to the development of tourist industry in the tourism reception area [2].

Through adopting the formula of Excel software, the G (geographical concentration index) of major inbound tourist market in Guangxi Province from 2006 to 2015 is computed, and the variation diagram of geographical concentration index of inbound tourism market in Guangxi Province from 2006 to 2015 is made (as shown in Figure 2).

From Figure 2, it is acquired that the geographical concentration index of Guangxi's inbound tourism market tends to increase yearly, as G has increased from 42.7 in 2006 to 49.4 in 2015, bespeaking that the geographical concentration index of Guangxi's inbound tourism market turns out to be increasingly larger, the origin countries and origins of tourists tend to be concentrated, the anti-risk capacity is lower. For this reason, the stable development of the inbound tourism market cannot be boosted.

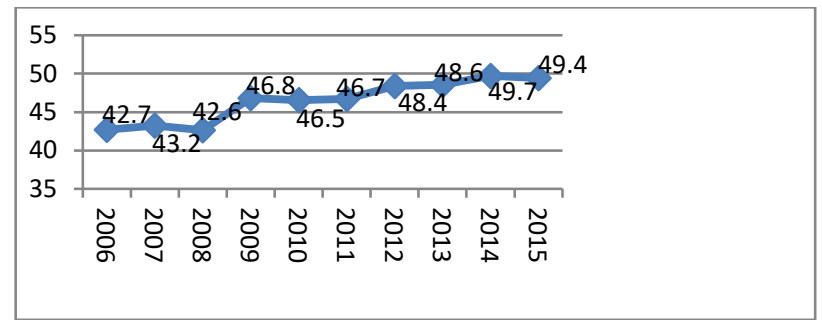

Figure 2: Variation diagram of geographical concentration index of inbound tourism market in Guangxi Province from 2006 to 2015

\subsection{Analysis of Tourist Source Category}

The inbound tourist market in Guangxi Province consists of two parts, viz. foreigners and compatriots in Hong Kong, Macao and Taiwan. From Figure 3, it is acquired that the foreign tourists have long surmounted those from Hong Kong, Macao and Taiwan. For this reason, the foreigners remain the main body of inbound tourist market in Guangxi Province, whereas they have taken up the increasingly less place in this data, sliding from $61.2 \%$ in 2006 to $53.1 \%$. Certainly, the tourists from Hong Kong, Macao and Taiwan have been perceived as the important components of the inbound tourist market in Guangxi, taking up yearly growing proportion among the overall market, reaching $46.9 \%$ in 2015.

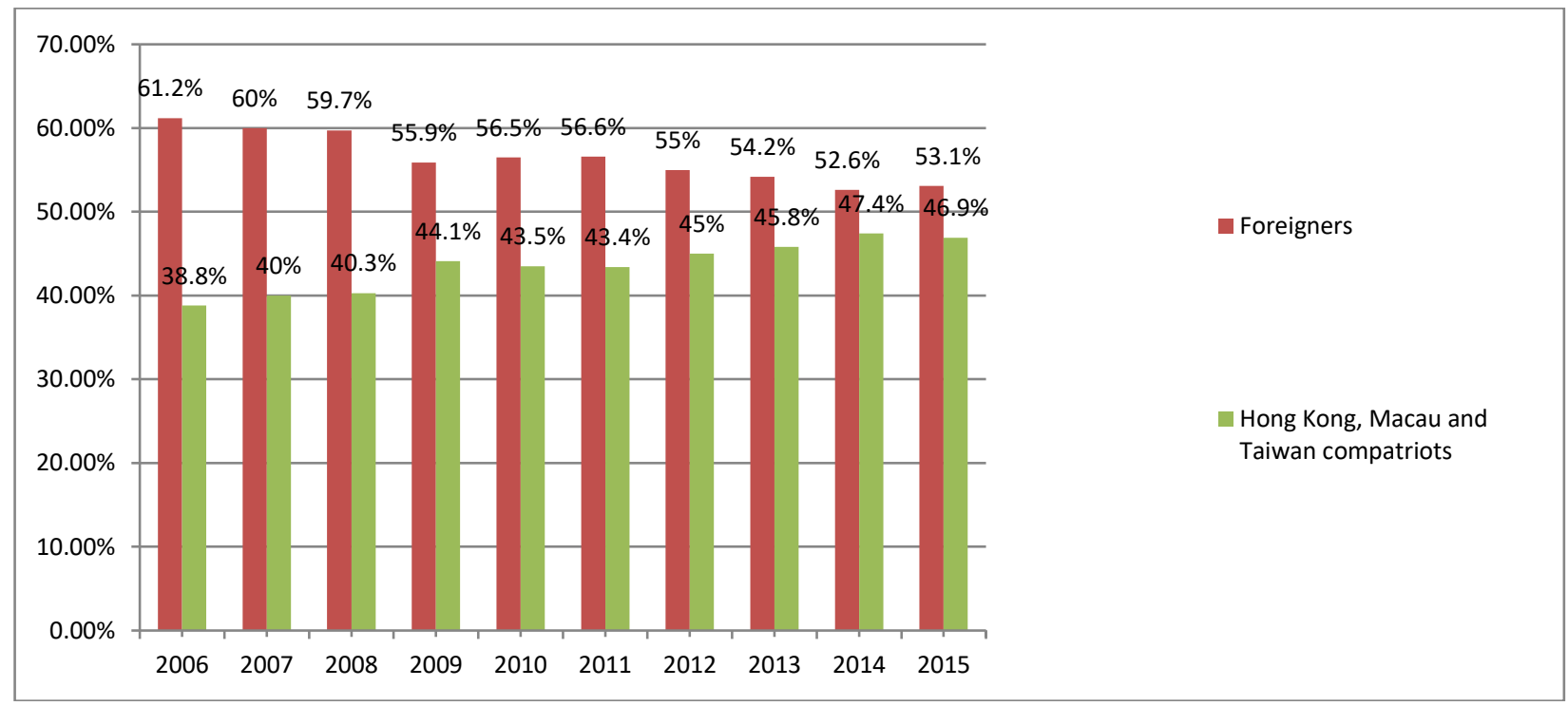

Figure 3: Inbound Tourist Category Constitution in Guangxi Province

\subsection{Analysis of Structure of Tourists' Origin Countries and Regions}

It is acquired from Table 1 and Figure 4 that tourists from Hong Kong, Macao and Taiwan have taken up the biggest place of the tourist source in Guangxi inbound tourism. In 2015, the tourists from Hong Kong, Macao and Taiwan have taken up 46.9\%, almost half of the overall market. As Guangxi borders on Vietnam, this country has always been deemed as the largest tourist origin country in inbound tourism of Guangxi Province, having been taking up 10.1\% in 2015. Hence it is spoken that the number of tourists' origin countries are dependent on the distance from the origin countries [3]. Korea has been deemed as the second largest origin country of inbound tourist in Guangxi, with fast growth of inbound tourist number. In 2006, it ranked the sixth place, and has progressively surmounted the numbers from Malaysia, Japan, America and France. In 2015, it turned out to be the second largest origin country of inbound tourist in Guangxi, with the strong developing momentum. The third largest origin country of inbound tourists is Malaysia. The American inbound tourists 
in Guangxi have been steadily growing year by year. The rest inbound tourist market in Guangxi has taken up from the largest to the smallest by Singapore, America, Indonesia, Thailand, France, Britain, Germany, Japan and Australia. The mentioned analysis's bespeak that tourists from Hong Kong, Macao and Taiwan, Korea, Vietnam and Malaysia take up the significant place in the inbound tourist market of Guangxi Province.

Notably, in 2006, Japan turned out to be the third largest tourists' origin countries of Guangxi's inbound tourism, whereas it has dropped in ranking since 2008 and ranked 11th in 2015. Such ranking dropping of Japan does not conform to Japan's status as the second largest tourists' origin countries of Guangxi's inbound tourism. For this reason, the inbound tourism from Japan to Guangxi shall be promoted as to reverse or alleviate the declining tendency.

Table 1: Inbound Tourist Number of Major Origin Countries of Tourist in Guangxi Province from 2006 to 2015 (10 thousand arrivals)

\begin{tabular}{|c|c|c|c|c|c|c|c|c|c|c|}
\hline $\begin{array}{l}\text { tourism-generating } \\
\text { region }\end{array}$ & 2006 & 2007 & 2008 & 2009 & 2010 & 2011 & 2012 & 2013 & 2014 & 2015 \\
\hline $\begin{array}{l}\text { Hong Kong, Macau and } \\
\text { Taiwan }\end{array}$ & 65.07 & 82.09 & 81.01 & 92.47 & 108.9 & 131.31 & 157.57 & 179.23 & 199.51 & 210.8 \\
\hline Vietnam & 18.75 & 23.4 & 17.23 & 22.87 & 29.23 & 37.95 & 48.67 & 45.08 & 42.75 & 45.36 \\
\hline Korea & 6.31 & 7.13 & 7.02 & 8.17 & 9.45 & 15.12 & 19.04 & 22.1 & 27.86 & 36.99 \\
\hline Malaysia & 13.81 & 11.87 & 11.37 & 16.2 & 19.01 & 24.25 & 24.25 & 28.14 & 27.97 & 28.17 \\
\hline Singapore & 2.19 & 2.33 & 4.2 & 5.21 & 5.4 & 8.46 & 10.08 & 12.98 & 13.14 & 15.17 \\
\hline America & 8.65 & 10.81 & 9.61 & 7.48 & 10.15 & 11.29 & 11.12 & 10.98 & 11.97 & 12.53 \\
\hline Indonesia & 1.62 & 2.04 & 1.42 & 2.31 & 6.76 & 7.7 & 9.68 & 13.41 & 11.77 & 12.13 \\
\hline Thailand & 5.23 & 5.04 & 5.03 & 4.58 & 3.06 & 5.16 & 8.16 & 10.67 & 8.66 & 10.55 \\
\hline France & 6.41 & 7.57 & 7.44 & 6.06 & 8.59 & 9.14 & 7.92 & 7.76 & 6.73 & 6.33 \\
\hline Britain & 3.66 & 4.92 & 5.29 & 4.02 & 5.4 & 5.67 & 4.91 & 5.25 & 5.69 & 6.25 \\
\hline Japan, & 3.52 & 4.39 & 3.98 & 3.57 & 5.15 & 5.58 & 5.52 & 5.6 & 5.01 & 5.11 \\
\hline Germany & 11.57 & 11.99 & 7.4 & 8.66 & 8.46 & 6.56 & 5.92 & 3.12 & 3.86 & 4.89 \\
\hline Australia & 0.75 & 1.15 & 4.18 & 3.52 & 4.53 & 4.65 & 4.55 & 4.29 & 4.68 & 4.23 \\
\hline
\end{tabular}

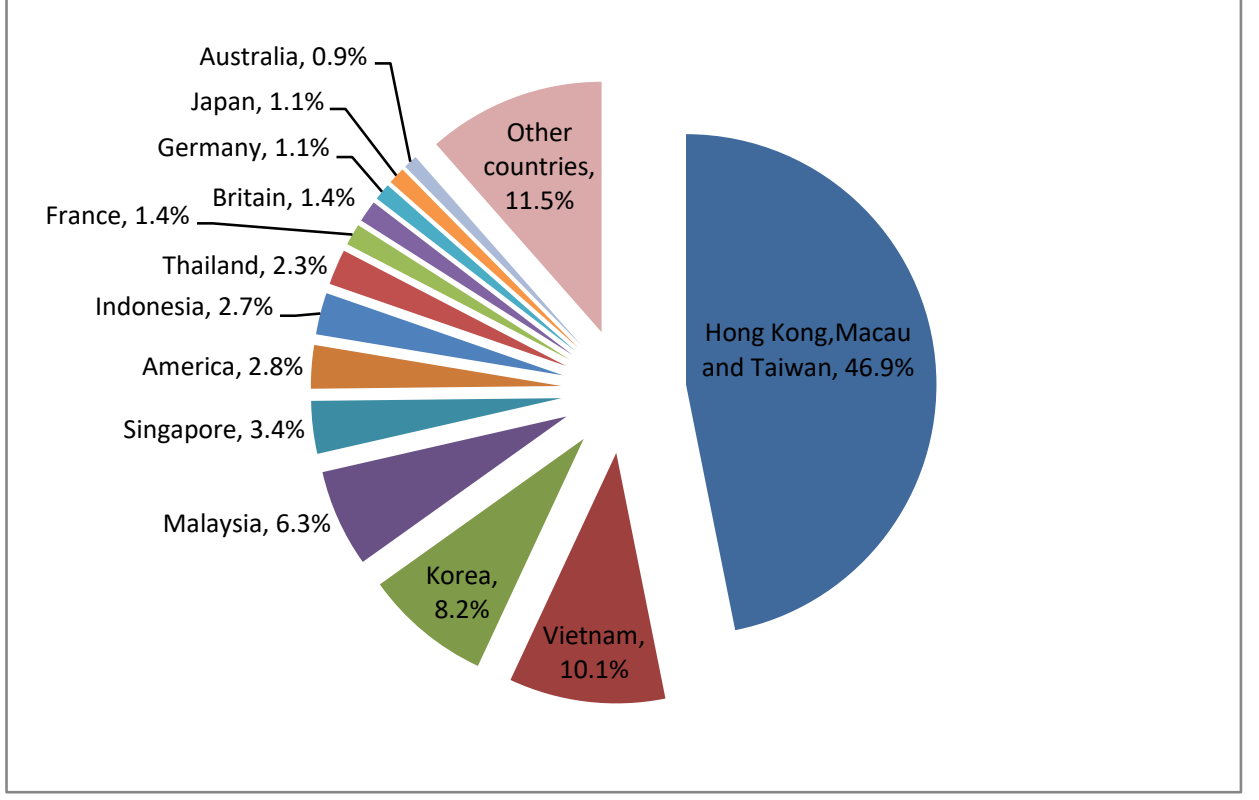

Figure 4: Occupancy Rate of Inbound Tourist Market in Guangxi Province in 2015

\section{CONCLUSIONS}

The geographical concentration index of inbound tourism market in Guangxi tends to increase, bespeaking that the origin count ries of tourists are relatively concentrated, and the anti-risk capacity is low, not conducing to the stable development of inbound tourism market.

The inbound tourist market in Guangxi is mainly taken up by the foreigners. Tourists from Hong Kong, Macao and Taiwan, Korea and Malaysia take up the most important place in the inbound tourist market in Guangxi. Hence, the measures shall be adopted to boost the stable development of these markets.

\section{REFERENCE}

[1] Yaofeng, M., Tianshun, L., Xinping, L. 2001. A Study on the Flowing Pattern of Tourists to China, China Higher Education Press, China.

[2] Jigang, B., Yifang, C. 2010. Geography of Tourism, Higher Education Press, China, 46-60.

[3] Peng, C., Ling, W., Chuanlong, H. 2012. The Source Market clustering analysis on Entry Tourists in Anhui. Journal of Hebei North University(social sciences), 28, 51-55. 